\title{
Obraz getta warszawskiego w literaturze polskiej. Rekonesans
}

\author{
The Image of the Warsaw Ghetto in Polish Literature: A Reconnaissance
}

\begin{abstract}
The author of this paper provides a synthetic discussion of the image of the Warsaw Ghetto in Polish poetry, prose, and drama. The Warsaw Ghetto is the one with most literary representations among all of the ghettos that have existed in the territories that were part of the Second Polish Republic before the war. The scholar presents the topic in chronological order, discussing the image of the closed Warsaw district during wartime, in the post-war era, the Stalinist period, the time from the 1950s to the 1980s, and after the year 1989. The most notable changes in the ghetto imagery occur after the year 1989, and are associated with the abolishment of censorship, the invasion of pop-cultural reframings of the subject, and the debuts of writers born after the war. In his analysis the author also considers texts that do not take up the topic of the Warsaw Ghetto directly and he points to traces that open up the possibility of classifying those texts as works about the Warsaw city-beyond-the-wall.
\end{abstract}

Keywords: Warsaw Ghetto, Polish literature, the Holocaust, history of the twentieth century

Streszczenie: Autor artykułu omawia syntetycznie obraz getta warszawskiego w polskiej poezji, prozie i dramacie. Ma ono najwięcej literackich realizacji spośród wszystkich gett istniejących na terenach dawnej Drugiej Rzeczpospolitej. Badacz prezentuje te tematykę w porządku chronologicznym omawiając obraz warszawskiej dzielnicy zamkniętej w czasie wojny, w epoce powojennej, stalinowskiej, od lat pięćdziesiątych do osiemdziesiątych oraz po roku 1989. Największe zmiany w obrazie getta dokonują się po roku 1989 i są związane ze zniesieniem cenzury, inwazją ujęć popkulturowych, pojawieniem się pisarzy urodzonych po wojnie. Autor poddaje refleksji również grupę tekstów, w których tematyka warszawskiego getta nie pojawia się bezpośrednio. Wskazuje ślady, według których można klasyfikować je jako utwory o warszawskim mieście za murem.

Słowa kluczowe: getto warszawskie, literatura polska, topika Holokaustu, historia XX wieku 


\section{Wstęp}

Bez wątpienia warszawska dzielnica zamknięta jest w piśmiennictwie polskim najpełniej reprezentowanym gettem spośród wszystkich istniejących na ziemiach dawnej II Rzeczpospolitej. Zadecydowały o tym zarówno jej rozmiary, umiejscowienie (w stolicy), skala dokonanej zbrodni, jak i legenda powstania wznieconego 19 kwietnia 1943 roku. Niezwykle obszernym działem piśmiennictwa traktującym o warszawskiej dzielnicy zamkniętej są przekazy wspomnieniowe i dokumentalne: pamiętniki, dzienniki, relacje świadków. Ich liczba - nawet jeśli weźmiemy pod uwagę tylko te utrwalone w języku polskim - jest imponująca. Do grupy tej zaliczają się przekazy fundamentalne dla światowej pamięci o Holokauście, jak dziennik Adama Czerniakowa, Pamiętnik Janusza Korczaka czy zespół dokumentów zgromadzonych w Archiwum Ringelbluma. Przywołajmy też - znajdujące się poza Archiwum Ringelbluma - pojedyncze relacje, notatki, pamiętniki i diariusze - często osób anonimowych. Rozległość i bogactwo tego materiału uświadamiają nam znawcy zagadnienia ${ }^{1}$. Jednak również dokładna lektura rodzimej prozy i poezji ujawnia zadziwiające bogactwo przedstawien „miasta za murem”. Po raz pierwszy problem obrazu getta warszawskiego w literaturze polskiej podjęła Irena Maciejewska we Wprowadzeniu do antologii Męczeństwo i zagtada Żydów w zapisach literatury polskiej².

Warszawska dzielnica zamknięta stanowi swoisty generator holokaustowych topoi. W tym zespole znajdują się takie, których nie można oderwać od dziejów getta w stolicy, gdyż to ono właśnie stanowi ich podstawowe (a niekiedy jedyne) źródło: Szmugler, Karuzela, Szmalcownik, Żydowscy Kolumbowie, Tamta stronalAryjska strona. Część z nich funkcjonuje na prawach ikony Zagłady (Karuzela, Stary Doktor, Umschlagplatz). Są to metonimie Holokaustu ${ }^{3}$. Dawno przekroczyły one obszar literatury, stając się elementem wyobrażeń filmowych, komiksowych, fragmentem społecznego imaginarium ${ }^{4}$. Najczęściej bodaj artystycznie eksploatowany jest temat Starego Doktora 5 .

${ }^{1}$ Zob. m.in. wykaz tekstów wspomnieniowych, relacji i źródeł pisanych w kompendiach: B. Engelking, J. Leociak, Getto warszawskie - przewodnik po nieistniejacym mieście, Warszawa 2001; J. Leociak, Biografie ulic. O żydowskich ulicach Warszawy. Od narodzin po Zagtade, Warszawa 2017.

${ }^{2}$ Zob. I. Maciejewska, Wprowadzenie [w:] Męczeństwo i zagtada Żydów w zapisach literatury polskiej, wyb., oprac. i wprow. I. Maciejewska, Warszawa 1988.

${ }_{3}^{3}$ M. Tomczok, Metonimie Zagtady. O polskiej prozie lat 1987-2012, Katowice 2013.

${ }^{4} \mathrm{Na}$ temat obecności obrazów związanych z gettem warszawskim i Zagładą w świadomości społecznej zob. Ślady Holokaustu w imaginarium kultury polskiej, red. J. Kowalska-Leder, P. Dobrosielski, I. Kurz, M. Szpakowska, Warszawa 2017.

${ }^{5}$ Najbogatszy zbiór wierszy o osobie i dziele Korczaka przynosi antologia w opracowaniu A. Szlązakowej Janusz Korczak w legendzie poetyckiej, Warszawa 1992. 


\section{Czas wojny}

Najwcześniejsze w literaturze zapisy getta pochodzą z czasów wojny. Należy tu wymienić przede wszystkim kilka uznanych dzieł, o których wiemy, że powstały jako bezpośrednia reakcja na los ginących: Campo di Fiori oraz Biedny chrześcijanin patrzy na getto Czesława Miłosza, Wielki Tydzień Jerzego Andrzejewskiego, Co czytatem umartym Władysława Szlengla czy Pieśni żatobne getta Izabeli Stachowicz (Gelbard). Nie są to jedyni twórcy, którzy już w trakcie okupacji zareagowali na tragedię „dzielnicy zamkniętej”. Jerzy Zagórski w 1943 roku kreśli Psalm. Jego pierwsze strofy brzmią:

O miasto ukochane,

Ulico bojem zryta...

Oko wciąż nową ranę

W kamieniach twoich czyta.

Obok placu Krasińskich

Armaty w getto bily.

Grzebieniem ognia błyskał

W tych ścianach każdy wyłom.

Zakrzepli, groźni ludzie

Tu patrzą zimnym wzrokiem.

Czas dusze ich wystudził

I twardym przykrył mrokiem.

Napływa strzałów wrzawa

Wraz z dymem z Muranowa:

Dołem jak mgła sinawa,

Góra jak chmura płowa.

O słońce wyrzynanych,

Dzieci zrzucanych w ogień,

Krwi brudnej krzepniesz plamą

W brązowym dymie trwogi ${ }^{6}$.

Pod psalmem Zagórskiego widnieje data: „1943”.

${ }^{6}$ J. Zagórski, Psalm [w:] Poezje, Warszawa 1983, s. 71. Utwór ukazał się po raz pierwszy w piśmie „Kultura Jutra” (1943, nr 6/7). Zob. Poezja Polski walczacej 1939-1945. Antologia, oprac. J. Szczawiej, Warszawa 1974, t. 2, s. 560. 
Najwybitniejszy poeta swojego pokolenia Krzysztof Kamil Baczyński Tren I pisze we wrześniu 1942 roku w trakcie Wielkiej Akcji, w kulminacyjnym punkcie eksterminacji warszawskiej dzielnicy zamkniętej. Tren I zawiera przejmujące słowa:
O ludu, ludu głuchy,
ty w bólu swym osobny,
jestżeś ty jeszcze ciałem,
czy już tylko swym duchem,
nikomu niepodobny,
w śmierci swojej osobny,
osobny w narodzeniu?

Passus ten wolno interpretować jako odnoszący się do Grosse Aktion ${ }^{8}$. Należy pamiętać, że Baczyński (ze strony matki Stefanii z domu Zieleńczyk) wywodził się ze zasymilowanej rodziny żydowskiej. Odmiennie jednak niż część jego krewnych nie znalazł się w getcie. Pozostał z matką po aryjskiej stronie. Przez pewien czas natomiast w Warszawie ukrywał się jego przyjaciel - poeta Jerzy Kamil Weintraub. Dla autora Historii getto i Zagłada miały więc także osobisty wymiar.

W inicjalnym numerze „Kuźnicy” z 1945 roku ukazało się ważne opowiadanie Adolfa Rudnickiego zatytułowane Wielkanoc. Wiemy, iż jego pomysł, notatki i pierwsze szkice „czynił autor współcześnie z wydarzeniami”9. Zespół tekstów prozatorskich traktujących o getcie warszawskim, a powstałych w czasie wojny, uzupełnia - zamieszczona w debiutanckim tomie Ślad - nowela Romana Bratnego $D w a j^{10}$.

Dopiero w 2014 roku poznaliśmy opowiadania Jerzego Jurandota Miasto skazanych. 2 lata w warszawskim getcie ${ }^{11}$. Jurandot spisywał je, ukrywając się po aryjskiej stronie. To scenki z życia getta: portrety ludzi, obrazy zdarzeń, utrwalone ręką świadka i ofiary. Teksty te mają dokładnie przemyślaną kompozycję. Są wycyzelowane, jakby emocje w ogóle nie targały narratorem. Jurandot w Mitości tragicznej czy Dziewczynie o ztotych warkoczach jest subtelnym stylistą. Brzmi to zaskakująco w kontekście świata, o którym traktują te teksty. W zderzeniu z koszmarem autor Dziejów śmiechu proponuje nie poetykę fragmentu (tak znaczącą dla późniejszych dzieł o Zagładzie), ale starannie dopracowane całostki.

${ }^{7}$ K.K. Baczyński, Tren I [w:] tegoż, Wiersze zebrane, Warszawa 2018, s. 396.

${ }^{8}$ Zob. T. Żukowski, Kręgiem ostrym rozdarty na pót. O niektórych wierszach K.K. Baczyńskiego z lat 1942-1943, „Teksty Drugie” 2004, nr 3, s. 151.

9 Wiemy też, że spłonęły w powstaniu warszawskim. Zob. I. Maciejewska, Wprowadzenie, dz. cyt., s. 22.

${ }^{10}$ R. Bratny, Dwaj [w:] tegoż, Ślad. Nowele, Warszawa 1946.

${ }^{11}$ J. Jurandot, S. Grodzieńska, Miasto skazanych. 2 lata w warszawskim getcie. Dzieci getta, Warszawa 2014. 
Liryka stanowi bogatszy zbiór niż proza powstała w latach 1939-1945. Nie tylko liczba, ale i głębia rozpoznań sytuuje wiersze powstałe hic et nunc ponad prozą. Poezja polska reaguje na eksterminację Żydów utworami najwyższej próby, dziełami wybitnymi, jak wspomniane już Campo di Fiori czy Biedny chrześcijanin patrzy na getto Miłosza, Co czytatem umartym Władysława Szlengla. Znacząca ich część znalazła się później w antologiach Michała Borwicza Pieśń ujdzie cato..., inne trafily do Poezji Polski walczacej Jana Szczawieja ${ }^{12}$.

Szlengel - podobnie jak Jurandot - sięga po tradycyjną formę, by mówić o doświadczeniach granicznych. Ta prostota jest przejmująca. To z pewnością najwybitniejszy poeta getta, co więcej, jeden z najwybitniejszych poetów Zagłady. Jego Kartka z dziennika „akcji”, Już czas, Rzeczy, Okno na tamtą stronę czy Mata stacja Treblinki to genialna, choć przerażająca, kronika dziejów miasta za murem $^{13}$. Ale ta prostota jest zdradliwa. Siła liryki Szlengla tkwi w „podwójnym kodowaniu”. Tomasz Żukowski tak widzi status poetyckiego wyznania:

Wydaje się, że wypowiada je ktoś rozdzierany sprzecznymi doznaniami i uczuciami. Dzięki ironicznej grze przeciwieństwa pozostają w ciągłym napięciu, a kontrastujące sensy podważają się nawzajem tak, że żaden nie zyskuje ostatecznej przewagi determinującej znaczenie całości ${ }^{14}$.

U Szlengla nie brakuje ironii, autoironii, sarkazmu, czarnego humoru i groteski.

Echa żydowskiej gehenny w stolicy szybko docierają też do autorów znajdujących się poza krajem. Co najmniej dwa wiersze poświęca warszawskiej dzielnicy zamkniętej Władysław Broniewski. W pierwszym oddaje hołd Szmulowi Zygielbojmowi, działaczowi Bundu, który w maju 1943 roku popełnił samobójstwo w proteście przeciwko milczeniu aliantów wobec ludobójstwa Żydów. Jemu to zadedykował Broniewski przejmujące wyznanie:

Z polskich miast i miasteczek nie słychać krzyków rozpaczy, padli, jak hufiec bojowy, warszawscy obrońcy getta...

Słowa me we krwi nurzam, a serce w ogromnym płaczu, dla was, o Żydzi polscy, polski tułaczy poeta ${ }^{15}$.

12 Pieśń ujdzie cato... Antologia wierszy o Żydach pod okupacja niemiecka, oprac. M.M. Borwicz, Warszawa-Łódź-Kraków 1947; Poezja Polski walczacej..., dz. cyt.

${ }_{13}$ W. Szlengel, Co czytatem umartym. Wiersze getta warszawskiego, oprac. I. Maciejewska, Warszawa 1977; Wtadystaw Szlengel-poeta nieznany. Wybór tekstów, oprac. M. Stańczuk, Warszawa 2013.

${ }_{14}$ T. Żukowski, Wtadystaw Szlengel - ironia a strategia świadectwa [w:] Ślady obecności, red. S. Buryła, A. Molisak, Kraków 2010, s. 125-126.

${ }^{15}$ W. Broniewski, Żydom polskim [w:] tegoż, Poezje, wyb., wstęp M. Józefacka, Lublin 1988, s. 173. 
W Ścianie ptaczu Broniewski przywołuje z bliskowschodniej perspektywy żołnierza generała Władysława Andersa los społeczności żydowskiej okrutnie mordowanej w świecie za murem.

W podobnym duchu, żalu i troski, reaguje Józef Wittlin w tekście Żydom $w$ Polsce. Zarówno wers: „Truciznę zażył gettowy twój burmistrz, Adam Czerniaków"16, jak i datacja (New York, 30 sierpnia 1942) wskazują, że autor Soli ziemi odpowiada słowami poetyckiego bólu na Wielką Akcję.

Oprócz twórców zawodowych - podobnie jak to jest w całym piśmiennictwie o Zagładzie - po pióro sięgali również amatorzy, osoby, które wcześniej tego nie czyniły albo robiły to sporadycznie. Trudno powiedzieć, ile dokładnie powstało takich „zapisów chwili”. Z pewnością nie wszystkie dotrwały do naszych dni. Niektóre (zgromadzone w zbiorach Żydowskiego Instytutu Historycznego) udostępniła szerszemu gronu odbiorców Bożena Keff w antologii Tango tez śpiewajcie muzy ${ }^{17}$. Świat $\mathrm{w}$ nich zapisany stanowi przede wszystkim przejaw indywidualnej ekspresji, w której chodzi nie tyle o artystyczną doskonałość, co o utrwalenie „prawdy czasu”. Miasto za murem portretowane jest $\mathrm{w}$ stanie emocjonalnego wrzenia. Tak jak w wierszu anonimowego autora Ptonace getto ${ }^{18}$.

\section{Zaraz po wojnie, stalinizm i epoka PRL}

Nim nastała noc stalinizmu, proza i poezja polska niejednokrotnie ręką wybitnych autorów opisywała gehennę Żydów. Zaraz po wojnie powstają Pożegnanie z Mariq Tadeusza Borowskiego, Medaliony Zofii Nałkowskiej, Czarny potok Leopolda Buczkowskiego, Szpital Przemienienia Stanisława Lema, Rzecz ludzka Mieczysława Jastruna, Pamiętnik mitości Stanisława Wygodzkiego. W tej grupie znajdują się też utwory poświęcone warszawskiej dzielnicy zamkniętej. Oprócz Kobiety cmentarnej z Medalionów i wierszy z Rzeczy ludzkiej w tym samy czasie Adolf Rudnicki publikuje przywoływaną już Wielkanoc, a Stefan Otwinowski dramat pod takim samym tytułem. To moment, gdy pamięć wojny jest jeszcze bardzo żywa, gorąca. Przeważają teksty, których twórcy doświadczyli epoki pieców, a ich pierwszą i podstawową reakcją jest chęć zaświadczenia prawdy o tym, co się stało, wyrażenia bólu i głosu protestu. Mimo olbrzymiej presji zdarzeń,

${ }_{16}$ J. Wittlin, Żydom w Polsce [w:] tegoż, Poezje, Warszawa 1981, s. 125.

17 Tango tez śpiewajcie muzy. Poetyckie dokumenty Holokaustu, wstęp, wyb., oprac. B. Keff, Warszawa 2012.

18 [Autor nieznany], Ptonące getto [w:] Poezja Polski walczaccej..., dz. cyt., t. 1, s. 466-467. Jan Szczawiej w drugim tomie swej antologii pisze: „Wiersz nieznanego dotąd autora. Drukowany w konspiracyjnej broszurze o zagładzie getta pt. Na oczach świata, wydanej przez Marię Kann w listopadzie 1943 roku w Warszawie. Był tam sygnowany literami "J.Z.T.»" (Poezja Polski walczącej..., dz. cyt., t. 2, s. 388). 
rozmiarów widzianego i doświadczonego okrucieństwa, poezja i proza polska nie popada w łatwe moralizatorstwo, dystansuje się też od estetyki krzyku. Jeśli go znajdziemy, to - jak w Kobiecie cmentarnej albo w tytułowym opowiadaniu z tomu Pożegnanie z Marią - nie na powierzchni, lecz ukryty, pod gorzką ironią, pod rzeczowym sprawozdaniem z tego, jak wyglądał świat odgrodzony wysokim murem. Podobnie będzie również w prozie lat pięćdziesiątych, sześćdziesiątych i siedemdziesiątych sięgającej po temat warszawskiego getta.

Pośród licznych obrazów, jakie spotkamy w literaturze zaraz po wojnie, odnotujmy jeden szczególnie znaczący. W Mieście niepokonanym Kazimierz Brandys powstanie w getcie stawia obok powstania z 1 sierpnia 1944 roku - włączając obydwa na tych samych prawach w tragiczną historię Warszawy. Żydowski bunt z kwietnia 1943 roku autor Samsona pojmuje jako „szczodry dar” - przykład dla pozostałych mieszkańców. W desperackim geście młodych bojowników Brandys widzi czyn racjonalny:

Ich rachunek był trzeźwy. Czułem potęgę tej trzeźwości, rozwagę końcowego wyboru między szansą ratunku, o której niełatwo zwątpić nawet u kresu, a wielką szansą pamięci, jaka zostaje zawsze, gdy ludzka śmierć służy dobrom trwalszym i większym niż życie ${ }^{19}$.

Pisarz konstruuje tę analogię kilkanaście miesięcy po klęsce nazizmu. Nie stanowiła ona - nie tylko w PRL - reguły w powszechnej mentalności skłonnej raczej, by widzieć te dwa wydarzenia jako odrębne.

Od początku problem getta warszawskiego (i Holokaustu) stanowił drażliwy komponent polityki historycznej komunistów ${ }^{20}$. Całkowicie zawłaszczono go w latach 1949-1954. Nie był to dobry moment zarówno dla mówienia o losie Żydów, jak i o innych aspektach martyrologii wojennej. Władza stawiała nie na przeszłość i rozpamiętywanie doznanych cierpień, lecz na przyszłość. Z optymizmem patrzono przed siebie. Celem było stworzenie nowego człowieka - wolnego od okupacyjnych wspomnień (jeśli nie dotyczyły one bohaterskiej opowieści o zaangażowaniu ruchu komunistycznego w pokonanie hitleryzmu $)^{21}$. Z podnoszonym w sferze publicznej nakazem zapomnienia skorelowany był proces zapomnienia architektonicznego. Odbudowa Muranowa stawała się zarazem rugowaniem wszelkich śladów po dzielnicy żydowskiej ${ }^{22}$.

W stalinowskiej wizji rzeczywistości dzieje getta należało przedstawiać w określonych ramach: wrogowi zewnętrznemu odpowiada wróg wewnętrzny

19 K. Brandys, Miasto niepokonane, Warszawa 1964, s. 192.

${ }^{20}$ Zob. między innymi Z. Wóycicka, Przerwana żatoba. Polskie spory wokót pamięci nazistowskich obozów koncentracyjnych i zagtady 1944-1950, Warszawa 2009.

${ }^{21}$ M. Mazur, O cztowieku tendencyjnym... Obraz nowego cztowieka w propagandzie komunistycznej w okresie Polski Ludowej i PRL 1944-1956, Lublin 2009.

${ }_{22}$ Zob. na ten temat B. Chomątowska, Stacja Muranów, Wołowiec 2016; J. Leociak, dz. cyt. 
(Judenraty, Policja Porządkowa, ludność „klasowo obca”: kupcy, fabrykanci i działacze syjonistyczni). To ,judenracko-policyjno-lumpenburżuazyjno-dyrektorska warstwa, która wyssała resztki krwi z getta"23. Bernard Mark aktywność lewicującej młodzieży (skupionej między innymi wokół ŻOB) przeciwstawiał bierności Judenratów i „lumpenburżuazji”. Ten punkt widzenia skorelowany był z innym, w którym „walkę getta warszawskiego powiązano z walką całego narodu polskiego i całego frontu antyfaszystowskiego pod egidą ZSRR"24. W poezji najpełniej stalinowską wizję powstania ilustruje poemat Adama Włodka $Z$ czerwonego życiorysu Warszawy ${ }^{25}$.

Trzeba jednak powiedzieć, że w zalewie miernych artystycznie tekstów doby socrealizmu znajdziemy co najmniej jeden, który - choć niesprawiedliwy w ocenie rzeczywistości - wyrasta nieco ponad inne. Chodzi o Pokolenie Bohdana Czeszki ${ }^{26}$. Dzieje getta zajmują ważne miejsce w tym zideologizowanym przekazie. Komuniści żydowscy - jak Dawid Sznajder, młody malarz rwą się do walki z hitlerowcami. Dzielni żydowscy komuniści mają swoich odpowiedników w dzielnych polskich komunistach - jedynych, którzy nie sięgają po własność żydowską (powieść ukazuje dwie grupy ludzi wzbogacających się na żydowskim złocie: przedsiębiorców przejmujących maszyny po byłych właścicielach oraz sympatyków podziemia). Mimo tych uproszczeń warstwa fabularna i portret niektórych postaci odbiegają od socrealistycznej sztampy.

Drugim tekstem wartym uwagi jest Mosiek, syn komunisty Władysława Kowalskiego. Ideologiczne przekłamania nie są w stanie przyćmić niekłamanego współczucia, jakie rodzi historia małego żydowskiego szmuglera ${ }^{27}$. Ten zaś wyrasta na autentyczną postać, przekraczającą ramy socrealistycznej sztampy.

Klasowa interpretacja zarówno eksterminacji Żydów, jak i powstania w getcie warszawskim nie ustała wraz z kresem realizmu socjalistycznego, śmiercią Stalina i odsunięciem od władzy jego polskich akolitów. Mocno zideologizowane utwory - podobne w wymowie do Pokolenia - napotkamy jeszcze i po tym okresie. Przykładem jest tom Flory Bieńkowskiej Smuga światta ${ }^{28}$. W latach osiemdziesiątych - już nie z pozycji ideologicznych, a z cynicznej, antysemickiej perspektywy - tragedię Żydów stolicy ukaże Bratny w opowiadaniach Dawid syn Henryka oraz Im gtębsza noc... ${ }^{29}$.

${ }^{23}$ B. Mark, Powstanie w getcie warszawskim na tle ruchu oporu w Polsce. Geneza i przebieg, Warszawa 1953, s. 35.

${ }^{24}$ R. Kobylarz, Walka o pamięć. Polityczne aspekty obchodów rocznicy powstania w getcie warszawskim 1944-1989, Warszawa 2009, s. 73.

25 A. Włodek, Z czerwonego życiorysu Warszawy, „Życie Literackie” 1953, nr 16.

26 B. Czeszko, Pokolenie, Warszawa 1951.

27 W. Kowalski, Mosiek, syn komunisty [w:] tegoż, Bestia, Warszawa 1951.

${ }^{28}$ F. Bieńkowska, Smuga światta, Warszawa 1961.

${ }^{29}$ R. Bratny, Dawid syn Henryka, Im gtębsza noc... [w:] tegoż, Twarde ojczyzny. Opowiadania, Warszawa 1986. 
Poezja i proza od Października do połowy lat osiemdziesiątych wielokrotnie kreśliła wizję warszawskiej dzielnicy zamkniętej. Najczęściej czynili to Stanisław Wygodzki (Rondo, W deszczu), Anna Kamieńska (Ktamstwo doktora Korczaka, Sen o Januszu Korczaku), Adolf Rudnicki (Moja czarna broda, Żywe i martwe morze, Ginacy Daniel, Ztote okna), Igor Newerly (Rozmowa w sadzie piatego sierpnia, Żywe wiąanie), Bogdan Wojdowski (Chleb rzucony umartym, Krwaworaczka, Awantura na Krochmalnej, Tamta strona, Stary doktor, Plac Grzybowski). W Odczytaniu popiotów (jednym z najwybitniejszych tomów literatury polskiej o Zagładzie) w przejmujących lirykach swój ból wyrażał Jerzy Ficowski (Sześcioletnia z getta żebrzaca na Smolnej w 1942 roku, 5 VIII 1942, Wniebowzięcie Miriam z ulicy zima 1942). Jego dzieła napawają niewypowiedzianym smutkiem.

Epopeję miasta za murem - historię jego powstania, naznaczonej głodem egzystencji oraz straszliwego końca - przynosi Chleb rzucony umartym Bogdana Wojdowskiego. Czytamy: „Opowiadanie określone jest dniem, kiedy mur zamknięto jesienią 1940 roku, i "wielką akcją" w 1942, kiedy w części dzielnicy przestał czemukolwiek służyć"30. Wspomnianą epopeiczność - paradoksalnie - udało się tu uzyskać „dzięki odejściu od tradycyjnej fabuły na rzecz przedstawiania epizodów, nieciągłej relacji (...)"31. Chleb rzucony umartym jest z pewnością najważniejszą powieścią o getcie warszawskim. Nowoczesną formę łączy z rekonstrukcją tradycyjnego żydowskiego świata przedwojennej Warszawy.

Autorem, o którym trzeba wspomnieć osobno, jest Stanisław Benski ${ }^{32}$. To obecnie prozaik zapomniany, funkcjonujący na marginesach recepcji czytelniczej (nawet gdy myślimy o znawcach tematyki Holokaustu). Jego krótkie opowiadania - utrzymane w charakterystycznej stylistyce, w której delikatny humor, nostalgia, pamięć o świecie sprzed Zagłady przeplatają się ze scenami grozy - wielokrotnie odsyłają do dziejów warszawskiego getta. Fabuła kilkunastu z nich jest mocno osadzona w realiach dzielnicy zamkniętej, a dokładnie mówiąc - w cienkim niczym pajęczyna, ulotnym (choć często mocno nasycającym zmysły) wspomnieniu świata sprzed powstania muru oraz - późniejszego - odgrodzonego od reszty Warszawy (Jeden dzień, Strażnik świąt, Dwie ulice i kozie różdżki, Trzy gatazki biatego bzu i trzy tulipany).

Z epoki PRL przywołajmy jeszcze jeden (niesłusznie zapomniany) tekst. Ztota czara Barbary Nawrockiej-Dońskiej to w literaturze polskiej bodaj jedyny utwór w całości poświęcony bohaterskiemu przywódcy powstania Mordechajowi Anielewiczowi (w powieści skrytego pod postacią Daniela) ${ }^{33}$.

30 B. Wojdowski, Chleb rzucony umartym, Warszawa 1979, s. 5.

31 A. Molisak, Judaizm jako los. Rzecz o Bogdanie Wojdowskim, Warszawa 2004, s. 107.

${ }^{32}$ Na temat jego twórczości zob. S. Buryła, Stanistaw Benski - kronikarz „osmalonych” [w:] tegoż, Wokót Zagtady. Szkice o literaturze Holokaustu, Kraków 2013.

${ }^{33}$ B. Nawrocka-Dońska, Ztota czara, Warszawa 1979. 
Otrzymujemy portret monumentalny, heroiczny, wzorowany na konwencji legendy, ale przede wszystkim odmalowany pędzlem polskiej kultury romantycznej. Daniel (Anielewicz) jest rozmiłowany w Adamie Mickiewiczu (Sonety krymskie) i Juliuszu Słowackim (Anhelli). Czuje się mocno związany z polską tradycją narodowo-wyzwoleńczą, z polskim etosem walki straceńczej. Według Nawrockiej-Dońskiej, przynależy on do tej samej generacji akowskiej, co młodzi polscy konspiratorzy: „Umierając miał 23 lata, był więc jednym z najmłodszych dowódców i komendantów zbrojnego zrywu, jaki notuje polska historia. Należał do pokolenia Kolumbów"34. Mordechaj Anielewicz, Marek Edelman, Antek (Icchak) Cukierman czy Jurek (Arie) Wilner to „żydowscy Kolumbowie"35, a więc młodzi Żydzi i Polacy pochodzenia żydowskiego, dla których centralnym doświadczeniem młodości był udział w powstaniu w getcie warszawskim ${ }^{36}$. Wyróżniają ich młody wiek, uczestnictwo w zbrojnym ruchu oporu, gotowość złożenia ofiary z życia, odwaga i konflikt z rodzicami, którzy wolą przyjąć postawę wyczekująca, nie prowokować okupanta. Przypomnijmy, że główny bohater powieści Romana Bratnego Kolumbowie. Rocznik 20. jest z pochodzenia Żydem ${ }^{37}$.

Uważa się niekiedy, że punktem przełomowym zarówno dla recepcji relacji polsko-żydowskich w świadomości społecznej, jak i historii literatury polskiej o Zagładzie, jest Poczatek Andrzeja Szczypiorskiego ${ }^{38}$. Tymczasem Poczatek nie wnosi nic nowego ani do artystycznych strategii opowiadania o getcie warszawskim, ani do artykulacji tak zwanych tematów niechcianych. Powieść Szczypiorskiego jest tradycyjna w formie, a podnoszone tak często w związku $\mathrm{z}$ nią prekursorstwo i odwaga $\mathrm{w}$ przedstawianiu problemów przejęcia żydowskiego majątku przez okupantów oraz polskich sąsiadów, jak również szmalcownictwa nie znajdują potwierdzenia w dziejach rodzimej prozy o Holokauście. Wystarczy spojrzeć choćby na utwory Wygodzkiego (na przykład Rondo), by się przekonać, że wcześniej niejednokrotnie sięgano już po te zagadnienia.

$\mathrm{Z}$ pewnością momentem zwrotnym w piśmiennictwie o warszawskim getcie i - szerzej - w refleksji nad Zagładą był esej Biedni Polacy patrzq na getto opublikowany na początku 1987 roku na łamach „Tygodnika Powszechnego” ${ }^{39}$. Jan Błoński - nawiązując do wiersza Miłosza Biedny chrześcijanin patrzy na getto - pytał:

34 Tamże, s. 11.

35 Na ten temat zob. S. Buryła, Żydowscy Kolumbowie [w:] tegoż, Tematy (nie)opisane, Kraków 2013.

36 Książka Anki Grupińskiej - Odczytanie listy - zawiera zbiór typowych życiorysów żydowskich Kolumbów urodzonych między rokiem 1918 a latami 1924-1925. Zob. A. Grupińska, Ciągle po kole. Rozmowy z żotnierzami getta warszawskiego, Warszawa 2000.

37 Więcej na ten temat zob. S. Buryła, Żydowscy Kolumbowie, dz. cyt.

38 A. Szczypiorski, Początek, Paryż 1986.

39 J. Błoński, Biedni Polscy patrzq na getto, „Tygodnik Powszechny” 1987, nr 2. 
Czyśmy im solidarnie pomogli? Ilu z nas uznało, że to nie ich rzecz! Pomijam zwykłych zbójców; myślę o tych, wcale licznych, co się po cichu cieszyli, że Hitler załatwił nam „problem żydowski”... (...) Słowem, miast się targować i usprawiedliwiać, winniśmy najpierw pomyśleć o sobie, o własnym grzechu czy słabości ${ }^{40}$.

Wątpliwość sformułowana przez Błońskiego do dziś wybrzmiewa mocnym tonem i do dziś stanowi zasadniczy przedmiot toczonych debat o relacjach polsko-żydowskich.

\section{Warszawska dzielnica zamknięta - nowe ujęcia}

Procesy polityczne i kulturowe następujące w Polsce i Europie Środkowo-Wschodniej po roku 1989 nie pozostały bez wpływu na literaturę o Szoa. Zasygnalizujmy tylko kwestie najbardziej oczywiste: zniesienie cenzury, przemiany cywilizacyjne, generacyjne, śmierć świadków. Sfera możliwych powiązań i oddziaływań między tymi zjawiskami oraz ich wpływu na obraz Zagłady to zjawisko wymagające odrębnej, pogłębionej refleksji. Nie ulega jednak wątpliwości, że wymienione czynniki modyfikowały obraz dzielnicy zamkniętej w polskiej prozie i poezji ostatnich trzech dekad. W początkach lat osiemdziesiątych w spojrzeniu rodzimej literatury na warszawskie getto pojawiły się trzy nowe perspektywy. Pierwsza związana jest z inwazją popkultury. Eksterminacja Żydów i - szerzej - realia II wojny światowej z niezwykłym impetem przenoszone są na teren współczesnej prozy popularnej, komiksu, do środowiska internetu i tak zwanych nowych mediów. Można nawet mówić o powstaniu w literaturze polskiej nowego nurtu - romansu holokaustowego ${ }^{41}$ czy fenomenu ostatnich czasów - kryminału retro. Proza popularna minionych dwóch dekad lubuje się w umieszczaniu fabuły w realiach okupacyjnych i wojennych.

W epoce PRL bardzo rzadko sięgano po narzędzia popkultury do mówienia o tragedii Żydów. Do najwcześniejszych przykładów wykorzystania schematu popkulturowego należy Poszukiwany Albert Peryt Jerzego Jesionowskiego ${ }^{42}$. Losy dzielnicy zamkniętej, informacje o warunkach życia, kolejnych wywózkach funkcjonują na marginesie głównego wątku - poszukiwania w getcie, a następnie przerzucenia na Zachód żydowskiego fizyka atomowego profesora Alberta Peryta. Sensacyjny schemat splata się u Jesionowskiego z przekazem

${ }^{40}$ Cyt. za: tenże, Biedni Polscy patrza na getto [w:] tegoż, Biedni Polacy patrza na getto, Kraków 2008, s. 29.

${ }^{41}$ M. Tomczok, Czyja dzisiaj jest Zagtada? Retoryka - ideologia - popkultura, Warszawa 2017.

42 J. Jesionowski, Poszukiwany Albert Peryt, Warszawa 1983. 
ideologicznym - odrzuceniem posądzeń o bierność i niedostateczne zaangażowanie państwa podziemnego w ratowanie Żydów.

Poszukiwany Albert Peryt zarysowuje obraz okupacyjnej Warszawy znany z kronik kryminalnych. Wraz z narratorem schodzimy do półświatka, gdzie prym wiodą szmuglerzy, prostytutki i kryminaliści (to świat, jaki odnajdujemy też w literaturze żydowskiej i polsko-żydowskiej doby międzywojnia ${ }^{43}$. Kilkadziesiąt lat później w te same mroczne strefy miasta za murem przeniesie nas Jerzy Stegner ${ }^{44}$. Wydana w 2010 roku Żydówka Noemi to romans z silnie wyeksponowanym wątkiem kryminalnym. Młody Polak - Leszek Groniewski próbuje odnaleźć na terenie getta żydowską piękność Noemi Zilberman. Podążając jej śladem, poznajemy drobnych warszawskich cwaniaków, stręczycieli i alfonsów, szpicli, szefów band, morderców. Kwitnie handel walutą i złotem (uczestniczą w nim Polacy, Żydzi i Niemcy). Nie brakuje też passusów obliczonych na ciekawość czytelniczą: pikantnych obrazów z domów publicznych w getcie, informacji o nocnym życiu w dzielnicy zamkniętej - zakazanych lokalach, ciemnych ludzkich sprawkach. Żydówka Noemi ma przecież opowiedzieć „ciekawą historię”, stylizowaną na autentyczną.

Ujęcie popkulturowe często ociera się o kicz. W wypadku getta warszawskiego z taką sytuacją mamy do czynienia nie tylko w przywołanej Żydówce Noemi, ale przede wszystkim w Księżniczce deptaku Marty Sztokfisz. Przedstawia ona wojenne i powojenne losy Edyty Klein. Okładkę przygotowano w konwencji charakterystycznej dla „czytadła”: widzimy twarz młodej, atrakcyjnej dziewczyny. Wyraz oczu, lekki uśmiech implikują historię, która skończy się szczęśliwie. Nota bene w podobnym romansowym duchu utrzymana jest okładka książki Stegnera.

Znajdziemy w Księżniczce deptaku sporo fałszu. Wypływa on niekontrolowanym, naturalnym strumieniem z duszy pięknej, egzaltowanej i próżnej kobiety. Klein czerpie wiele przyjemności z sentymentalnych powrotów do chwil, kiedy mogła kokietować urodą i uwodzić mężczyzn. Irytują również liczne nieporadności językowe, klisze i zbitki słowne. Zarówno u Jesionowskiego, jak i u Stegnera oraz Sztokfisz na pierwszym planie umieszczono nie losy umierających, lecz „przygody” głównych protagonistów, sensacja przesłoniła tragedię mieszkańców dzielnicy zamkniętej.

Konwencji popkulturowych eksploatowanych z zamiarem osiągnięcia zysku finansowego, łatwego szukania sensacji nie można mylić z ich świadomym wykorzystaniem i przetworzeniem. Tak się dzieje w Nocy żywych Żydów Igora Ostachowicza ${ }^{45}$. Wolno na tę powieść spojrzeć jak na realizację poetki kampowej. Jeśli tak, to w przypadku polskiej prozy o Holokauście należałoby Noc

${ }_{43}$ Zob. A. Molisak, Miasto i występek [w:] tejże, Żydowska Warszawa-żydowski Berlin. Literacki portret miasta w pierwszej potowie XX wieku, Warszawa 2016.

${ }^{44}$ J. Stegner, Żydówka Noemi, Gdańsk 2010.

45 I. Ostachowicz, Noc żywych Żydów, Warszawa 2012. 
żywych Żydów uznać za dzieło prekursorskie. Ale skojarzenie kampowe chyba nie wystarcza. Wszak powieść Ostachowicza stanowi przykład utworu zaangażowanego, walczącego ze stereotypami i mitami narodowymi, prezentującego ukryte kompleksy i nieprzepracowane problemy z przeszłości. Jak stwierdza jedna z interpretatorek Nocy żywych Żydów: „Noc... nie jest ani horrorem, ani powieścią sensacyjną, to właściwie gorzka komedia o traumie"46.

Książka Ostachowicza wywoływała sprzeczne emocje. Zarzucano jej wykorzystanie niestosownej formy do mówienia o poważnych sprawach ${ }^{47}$. Nie ulega jednak wątpliwości, że Noc żywych Żydów należy do istotnego nurtu w polskiej literaturze Holokaustu, który na różne sposoby próbuje przywrócić pamięć o pomordowanych Żydach oraz przestrzeni dokonanej zbrodni ${ }^{48}$. Zadanie, przed jakim stają polscy twórcy w ostatnich trzech dekadach, dobrze nakreśla Jacek Leociak: „Doświadczenie miejsca-po-getcie ma charakter paradoksalny. Jest to uobecnianie pustki. Ocalony wypełnia ją ułamkami pamięci fragmentarycznej, okaleczonej, zatartej. Wszyscy pozostali skazani są na projekcję własnych wyobrażeń” ${ }^{49}$. W tym nurcie natrafimy na dzieła autorów z tak zwanego trzeciego pokolenia. Piotr Paziński wydaje się najwybitniejszym przedstawicielem tej generacji. Stary, osamotniony Żyd z Ptasich ulic ${ }^{50}$ - niczym bohaterowie Benskiego - stara się wskrzesić ludzi, domy i ulice, których już nie ma. Odmiennie jednak niż u autora Strażnika świąt Izaak Feldwurm z tekstu Pazińskiego nie ogranicza się do jednego fragmentu getta, on zamierza w swoim dziele zapisać całość, tak by nic nie umknęło - żaden budynek, żadna ludzka egzystencja. To dług, który bohater opowiadania spłaca ofiarom Zagłady.

Po roku 1989 wciąż aktywni są prozaicy ze starszego pokolenia. Hanna Krall po publikacji w 1977 roku rozmów z Markiem Edelmanem (Zdążć przed Panem Bogiem) w swoich tomach kilkukrotnie powraca do tematu getta warszawskiego. W Obecności (z tomu Tam już nie ma żadnej rzeki) Krall zapowiada późniejszy zbiór utworów, w których pamięć pomordowanych Żydów staje się napastliwa, a jej artykulacja jawi się jako fizyczna konieczność: „Duchy upodobały sobie nowych mieszkańców na ulicy Andersa: niemłode małżeństwo, krawcową i kupca. Ich blok zbudowano na gruzach narożnej kamienicy. Czyjąś obecność poczuli przed paroma laty" ${ }^{51}$. Nie ma od nich i od niej ucieczki.

$\mathrm{Na}$ tle innych przestawień dzielnicy zamkniętej strategia artystyczna Krall jawi się jako oryginalna i ożywcza. Autorka Hipnozy łączy poetykę fragmentu

${ }^{46}$ J. Sobolewska, Mściciel z Muranowa, „Polityka” 2012, nr 15.

47 Problematykę tę omawia Beata Przymuszała, Smugi Zagłady. Emocjonalne i konwencjonalne aspekty tekstów ofiar i ich dzieci, Poznań 2016, s. 172-194.

48 B. Przymuszała, „Noc żywych Żydów” Igora Stachowicza - konwencje i emocje [w:] tejże, Smugi Zagtady, dz. cyt., s. 172-185.

49 J. Leociak, dz. cyt., s. 628.

${ }^{50}$ P. Paziński, Ptasie ulice, Warszawa 2013.

${ }^{51}$ H. Krall, Obecność [w:] tejże, Tam już nie ma żadnej rzeki, Kraków 2001, s. 128. 
ze stylistyką, którą jeden z krytyków nazwał baśniami dokumentalnymi ${ }^{52}$. Świat realny przenika się ze zjawiskami pochodzącymi z innego porządku - irracjonalnego, metafizycznego, z porządku niepamięci i zapomnienia. To bowiem, co odeszło w epoce Szoa, nie przeminęło całkowicie. Nie chce odejść, a ludzie, którzy żyli na obszarze dawnej dzielnicy zamkniętej domagają się odpowiedniego pożegnania, odprawienia ceremonii żałobnej. Obecność otwiera miejsce dla perspektywy konstytuującej Noc żywych Żydów Ostachowicza oraz Muranooo Sylwii Chutnik. „Masowo mordowani, niepochowani, nieopłakani i nieupamiętnieni przeistoczyli się w figurę zombie (...) lub po prostu w duchy, które wedle miejskiej legendy starszą na terenie warszawskiego Muranowa" ${ }^{53}$.

Małgorzata Wójcik-Dudek jest autorką monografii ilustrującej drugi prężny nurt zmian w podejściu do tematyki Holokaustu po 1989 roku $^{54}$. To sięgające po Szoa powieści dla dzieci i młodzieży. W tej grupie jest co najmniej kilka tekstów opowiadających o warszawskim getcie: Kotka Brygidy oraz XY Joanny Rudniańskiej, Szlemiel Ryszarda Marka Grońskiego, Arka czasu Marcina Szczygielskiego ${ }^{55}$.

Jak przekonuje badaczka:

współczesna „literatura czwarta” tworzona przez drugie, a w zasadzie już trzecie pokolenie posługuje się narracją, która jest wypadkową świadectwa oraz fikcyjnej opowieści złagodzonych w takim stopniu, aby odpowiadała wrażliwości i możliwościom percepcyjnym młodego odbiorcy ${ }^{56}$.

Ta taktyka - mówienia do dziecka przez pryzmat umysłowości oraz z pozycji i uwzględnieniem dziecięcej wrażliwości - okazuje się oryginalną propozycją także dla dorosłych czytelników (również dla historyków literatury i znawców zagadnienia).

O ile prezentowanie Szoa przez pryzmat dziecięcej świadomości nie jest niczym nowym, o tyle Zagłada opowiedziana dziecięcemu odbiorcy to zjawisko nowe, mające ciekawe realizacje artystyczne. Wykorzystując tę konwencję, Marcin Szczygielski w utworze Arka czasu, czyli wielka ucieczka Rafata od kiedyś przez wtedy do teraz i wstecz przedstawia gettową rzeczywistość, w której imaginacja żydowskiego chłopca dokonuje przemieszania porządku realnego i baśniowego, rzeczywistości i sztuki. Podobnie dzieje się w Kotce Brygi$d y, X Y$ oraz Szlemielu.

52 M. Cichy, Baśnie dokumentalne Hanny Krall, „Gazeta Wyborcza” 1999, nr 19.

53 Zob. hasło Szafa J. Kowalskiej-Leder [w:] Ślady Holokaustu..., dz. cyt., s. 389.

${ }_{54}$ M. Wójcik-Dudek, W(y)czytać Zagtadę. Praktyki postpamięci w polskiej literaturze XXI wieku dla dzieci i mtodzieży, Katowice 2016.

55 J. Rudniańska, Kotka Brygidy, Żabia Wola 2007; taż, XY, Warszawa 2012; R.M. Groński, Szlemiel, Warszawa 2010; M. Szczygielski, Arka czasu, czyli wielka ucieczka Rafata od kiedyś przez wtedy do teraz i wstecz, Warszawa 2013.

56 M. Wójcik-Dudek, dz. cyt., s. 135. 
Należy jednak mieć świadomość, że w polskiej poezji i prozie znajduje się niemała grupa dzieł, w których miasto za murem stanowi znaczący, ale nie jedyny (nie zasadniczy) wątek. Wystarczy ponownie przywołać Kolumbów. Rocznik 20. Romana Bratnego, Tryptyk oświęcimski Joanny Kulmowej (jego ostatnia część dedykowana jest pamięci Janusza Korczaka), Życie ideologiczne Henryka Grynberga, Króla kier znów na wylocie, Podwórko i Życie Hanny Krall (z tomu Tam już nie ma żadnej rzeki) ${ }^{57}$. Kazimierz Wierzyński w liryku Do Żydów (budując analogie między losem dwóch narodów i dwóch powstań) w przedostatniej strofie woła:

Tak doświadczony, gdyś powstał w Warszawie,

By choćby ginąć, lecz wolnym nareszcie,

Spójrz, co zostało po krwi i sławie

$\mathrm{Z}$ naszej świątyni powstańcom w tym mieście ${ }^{58}$.

Trudno jednak uznać, że jest to utwór, w którego centrum znajduje się tragedia warszawskiego getta.

Istnieje też inny zbiór liryków, powieści i opowiadań, ten, w którym dzielnica zamknięta nie pojawia się wprost. Jest zaledwie suponowana. W Przybyszu z Narbony Juliana Stryjkowskiego znajdujemy dedykację: Powstańcom Getta Warszawskiego poświęcam ${ }^{59}$.

Jak zakwalifikować utwory takie jak nowela Jana Himilsbacha Nasza ulica? ${ }^{30} \mathrm{O}$ chłopcu, który pojawia się na „naszej ulicy” (warszawskiej?), czytamy: „Przyszedł na naszą ulicę nie wiadomo skąd” ${ }^{61}$. Być może uciekł z „miasta za murem”, może ukrywa go jakaś polska rodzina (w Warszawie?). Wiemy tylko, że był „brudny, obdarty” i ciągnął za sobą sanki.

Monika Kotowska w tomie Most na drugą stronę zamieszcza kilka obrazów, których tematyka wyraźnie odsyła do losów warszawskiej dzielnicy zamkniętej. Pisarka nie daje przy tym wskazówek topograficznych, nigdzie nie pojawia się nazwa „Warszawa”. Otrzymujemy zestaw pośrednich śladów. To sceny, które niemal automatycznie kojarzymy z gettem w stolicy. W opowiadaniu Wyptata będzie w niedziele grupa małych szantażystów czyha na Żydów wychodzących z getta. Bohaterka noweli Zaczarowana uliczka pyta: „Tam, na tej zaczarowanej uliczce, nie będzie nieżywych dziewczynek, przykrytych gazetami?”'22.

57 R. Bratny, Kolumbowie. Rocznik 20., Warszawa 1957; J. Kulmowa, Tryptyk oświęcimski [w:] tejże, Cykuta, Warszawa 1967; H. Grynberg, Życie ideologiczne. Życie osobiste, Warszawa 1992; H. Krall, dz. cyt.

${ }^{58}$ K. Wierzyński, Do Żydów [w:] tegoż, Poezja, wyb., posł. M. Sprusiński, Kraków 1981, s. 262.

59 J. Stryjkowski, Przybysz z Narbony, Warszawa 1978.

${ }^{60}$ J. Himilsbach, Nasza ulica [w:] tegoż, Opowiadania zebrane, Kraków 2008.

${ }^{61}$ Tamże, s. 17.

${ }^{62}$ M. Kotowska, Zaczarowana uliczka [w:] tejże, Most na drugą stronę, Warszawa 1963. 
Wspomnienie trupów przykrytych papierem, gazetami wielokrotnie powraca w tekstach ocalonych. Zacytujmy dłuższy passus z Czarnych sezonów Michała Głowińskiego:

Kolor getta jest w moim wspomnieniu kolorem papieru, jakim przykrywano leżące na ulicy trupy, zanim je uprzątnięto. A należały one do stałego krajobrazu, ulica była miejscem nie tylko śmierci nagłych i niespodziewanych, była miejscem powolnego konania - z głodu, z chorób, z wszelkich innych możliwych powodów. (...) Przykryte płachtą papieru zwłoki robiły na mnie zawsze ogromne wrażenie. To właśnie ten papier stał się dla mnie jednym z ucieleśnień śmierci, jednym z jej symboli ${ }^{63}$.

Jeszcze inny rodzaj problemów wprowadzają teksty, w których nie natrafimy na żadne tropy naprowadzające na rzeczywistość charakterystyczną dla warszawskiej dzielnicy zamkniętej, mówiąc inaczej - na teksty, który ukazują sytuacje modelowe dla Zagłady, pasujące zarówno do getta w Warszawie, Łodzi, jak i Białymstoku, czy jakiegokolwiek innego. Do takich dzieł należy choćby miniatura Romana Brandstaettera Jeszcze jedna rozmowa ze Szmulikiem ${ }^{64}$. W tej grupie wypada też umieścić znany wiersz Wisławy Szymborskiej Jesz$c z e^{65}$. Ukazuje on ostatni etap likwidacji gett - wywózkę do ośrodków zagłady. Można go przecież czytać jako „komentarz” do Wielkiej Akcji zapoczątkowanej 22 lipca 1942 roku. Analogicznie sytuacja wygląda w wypadku znakomitej noweli $M u z y k a^{66}$. Wiem, że jej autor, Wiktor Woroszylski, przebywał wraz $\mathrm{z}$ rodziną $\mathrm{w}$ getcie grodzieńskim ${ }^{67}$. Jeśli jednak zapomnieć o tej wiedzy, można miniaturę Woroszylskiego potraktować jako opowieść o prawach obowiązujących w rzeczywistości każdego innego getta (także warszawskiego).

Wymieńmy na koniec tego niepełnego wykazu krótki tekst Anny Kamieńskiej Pan Goldberg ${ }^{68}$. Czy mówi on o getcie warszawskim czy lubelskim (w Lublinie okupację częściowo spędziła Kamieńska)? A może świadomie - jak Muzyka abstrahuje od przyporządkowań topograficznych, koncentrując się na pochwyceniu konkretnej sceny, momentu znaczącego dla holokaustowych narracji.

Jak można zauważyć, dominują przekazy poetyckie i prozatorskie, nieliczny zbiór stanowi dramat. Jakkolwiek utworów z tego ostatniego obszaru nie ma zbyt wiele, trzeba przyznać, że natrafimy tu na co najmniej jeden ważny -

${ }^{63}$ M. Głowiński, Czarne sezony, Kraków 2002, s. 11-12.

${ }^{64}$ R. Brandstaetter, Jeszcze jedna rozmowa ze Szmulikiem [w:] tegoż, Bardzo krótkie i nieco dtuższe opowieści, Poznań 1984.

65 W. Szymborska, Jeszcze [w:] tejże, Wotanie do Yeti, Kraków 1957.

${ }^{66}$ W. Woroszylski, Muzyka [w:] tegoż, Okrutna gwiazda, Warszawa 1958.

${ }^{67} \mathrm{Na}$ ten temat zob. W. Woroszylski, Dzienniki, t. 1: 1953-1982, oprac. A. Dębska, Warszawa 2017.

${ }^{68}$ A. Kamieńska, Pan Goldberg [w:] tejże, Czasy matego szczęścia, Łódź 1963. 
Wielkanoc Stefana Otwinowskiego ${ }^{69}$. Wśród innych wartych przywołania wymieńmy też Smoczą 13 Zofii Zahorskiej ${ }^{70}$, Mitość szuka mieszkania Jerzego Jurandota $^{71}$ oraz Kabaret po tamtej stronie Henryka Grynberga ${ }^{72}$.

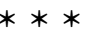

Teksty prozatorskie i poetyckie dotyczące miasta za murem można pogrupować w trzy zespoły. Podstawę ich podziału stanowi czas powstania. Nie chodzi jednak o to, by dokładnie, co do roku, uszeregować poszczególne utwory. Wiedza o dacie powstania utworu stanowi jednak ważną informację dla czytelnika. Nie jest bez znaczenia bowiem, czy wiersz, powieść albo opowiadanie rodziły się w bezpośrednim sąsiedztwie zdarzeń (jeszcze w trakcie wojny), w peerelowskiej rzeczywistości, czy po epoce transformacji światopoglądowej i cywilizacyjnej na przełomie lat osiemdziesiątych i dziewięćdziesiątych XX wieku. Chodzi o trzy limesy: teksty powstałe w trakcie trwania hitlerowskiej okupacji, po wojnie, a przed przełomem końca lat osiemdziesiątych, oraz te powstate po przełomie politycznym 1989 roku. Zachowanie podstawowych ram porządku chronologicznego pozwala też zobaczyć wewnętrzną ewolucję strategii mówienia o tragedii warszawskiego getta.

\section{Bibliografia}

Baczyński K.K., Wiersze zebrane, Warszawa 2018.

Bieńkowska F., Smuga światta, Warszawa 1961.

Błoński J., Biedni Polacy patrza na getto, Kraków 2008.

Błoński J., Biedni Polscy patrzq na getto, „Tygodnik Powszechny” 1987, nr 2.

Brandstaetter R., Bardzo krótkie i nieco dtuższe opowieści, Poznań 1984.

Brandys K., Miasto niepokonane, Warszawa 1964.

Bratny R., Kolumbowie. Rocznik 20., Warszawa 1957.

Bratny R., Ślad. Nowele, Warszawa 1946.

Bratny R., Twarde ojczyzny. Opowiadania, Warszawa 1986.

Broniewski W., Poezje, wyb., wstęp M. Józefacka, Lublin 1988.

Buryła S., Tematy (nie)opisane, Kraków 2013.

Buryła S., Wokót Zagłady. Szkice o literaturze Holokaustu, Kraków 2013.

69 S. Otwinowski, Wielkanoc, Kraków 1946.

70 S. Zahorska, Smocza 13, Rzym 1945.

${ }^{71}$ J. Jurandot, S. Grodzieńska, Mitość szuka mieszkania [w:] tychże, Miasto skazanych..., dz. cyt.

${ }^{72}$ H. Grynberg, Kabaret po tamtej stronie, „Dialog” 1997, nr 8. Dramaty autorów Trzeciego dzwonka oraz Prawdy nieartystycznej do nakreślonej przez Otwinowskiego i Zahorską perspektywy powstania w getcie warszawskim dodają „,codzienność Zagłady”. 
Chomątowska B., Stacja Muranów, Wołowiec 2016.

Cichy M., Baśnie dokumentalne Hanny Krall, „Gazeta Wyborcza” 1999, nr 19.

Czeszko B., Pokolenie, Warszawa 1951.

Engelking B., Leociak J., Getto warszawskie - przewodnik po nieistniejącym mieście, Warszawa 2001.

Głowiński M., Czarne sezony, Kraków 2002.

Groński M.R., Szlemiel, Warszawa 2010.

Grupińska A., Ciagle po kole. Rozmowy z żotnierzami getta warszawskiego, Warszawa 2000.

Grynberg H., Kabaret po tamtej stronie, „Dialog” 1997, nr 8.

Grynberg H., Życie ideologiczne. Życie osobiste, Warszawa 1992.

Himilsbach J., Opowiadania zebrane, Kraków 2008.

Janusz Korczak w legendzie poetyckiej, oprac. A. Szlązakowa, Warszawa 1992.

Jesionowski J., Poszukiwany Albert Peryt, Warszawa 1983.

Jurandot J., Grodzieńska S., Miasto skazanych. 2 lata w warszawskim getcie, Dzieci getta, Warszawa 2014.

Kamieńska A., Czasy matego szczęścia, Łódź 1963.

Kobylarz R., Walka o pamięć. Polityczne aspekty obchodów rocznicy powstania w getcie warszawskim 1944-1989, Warszawa 2009.

Kotowska M., Most na drugq stronę, Warszawa 1963.

Kowalski W., Bestia, Warszawa 1951.

Krall H., Tam już nie ma żadnej rzeki, Kraków 2001.

Kulmowa J., Cykuta, Warszawa 1967.

Leociak J., Biografie ulic. O żydowskich ulicach Warszawy. Od narodzin po Zagtade,, Warszawa 2017.

Mark B., Powstanie w getcie warszawskim na tle ruchu oporu w Polsce. Geneza i przebieg, Warszawa 1953.

Mazur M., O cztowieku tendencyjnym... Obraz nowego cztowieka w propagandzie komunistycznej w okresie Polski Ludowej i PRL 1944-1956, Lublin 2009.

Męczeństwo i zagtada Żydów w zapiskach literatury polskiej, wyb. oprac. i wprow. I. Maciejewska, Warszawa 1988.

Molisak A., Judaizm jako los. Rzecz o Bogdanie Wojdowskim, Warszawa 2004.

Molisak A., Żydowska Warszawa - żydowski Berlin. Literacki portret miasta w pierwszej potowie XX wieku, Warszawa 2016.

Nawrocka-Dońska B., Ztota czara, Warszawa 1979.

Ostachowicz I., Noc żywych Żydów, Warszawa 2012.

Otwinowski S., Wielkanoc, Kraków 1946.

Paziński P., Ptasie ulice, Warszawa 2013.

Pieśn ujdzie cato... Antologia wierszy o Żydach pod okupacją niemiecka, oprac. M.M. Borwicz, Warszawa-Łódź-Kraków 1947.

Poezja Polski walczącej 1939-1945. Antologia, t. 1-2, oprac. J. Szczawiej, Warszawa 1974. 
Przymuszała B., Smugi Zagtady. Emocjonalne i konwencjonalne aspekty tekstów ofiar i ich dzieci, Poznań 2016.

Rudniańska J., Kotka Brygidy, Żabia Wola 2007.

Rudniańska J., $X Y$, Warszawa 2012.

Sobolewska J., Mściciel z Muranowa, „Polityka” 2012, nr 15.

Stegner J., Żydówka Noemi, Gdańsk 2010.

Stryjkowski J., Przybysz z Narbony, Warszawa 1978.

Szczygielski M., Arka czasu, czyli wielka ucieczka Rafata od kiedyś przez wtedy do teraz i wstecz, Warszawa 2013.

Szczypiorski A., Początek, Paryż 1986.

Szlenegel W., Co czytatem umartym, oprac. I. Maciejewska, Warszawa 1977.

Szymborska W., Wotanie do Yeti, Kraków 1957.

Ślady Holokaustu w imaginarium kultury polskiej, red. J. Kowalska-Leder, P. Dobrosielski, I. Kurz, M. Szpakowska, Warszawa 2017.

Ślady obecności, red. S. Buryła, A. Molisak, Kraków 2010.

Tango tez śpiewajcie muzy. Poetyckie dokumenty Holokaustu, wstęp, wyb., oprac. B. Keff, Warszawa 2012.

Tomczok M., Czyja dzisiaj jest Zagtada? Retoryka - ideologia - popkultura, Warszawa 2017.

Tomczok M., Metonimie Zagtady. O polskiej prozie lat 1987-2012, Katowice 2013.

Wierzyński K., Poezja, oprac. M. Sprusiński, Kraków 1981.

Wittlin J., Poezje, Warszawa 1981.

Wtadystaw Szlengel - poeta nieznany. Wybór tekstów, oprac. M. Stańczuk, Warszawa 2013.

Włodek A., Z czerwonego życiorysu Warszawy, „Życie Literackie” 1953, nr 16.

Wojdowski B., Chleb rzucony umartym, Warszawa 1979.

Woroszylski W., Dzienniki, t. 1: 1953-1982, oprac. A. Dębska, Warszawa 2017.

Woroszylski W., Okrutna gwiazda, Warszawa 1958.

Wójcik-Dudek M., W(y)czytać Zagtadę. Praktyki postpamięci w polskiej literaturze XXI wieku dla dzieci i mtodzieży, Katowice 2016.

Wóycicka Z., Przerwana żatoba. Polskie spory wokót pamięci nazistowskich obozów koncentracyjnych i zagtady 1944-1950, Warszawa 2009.

Zagórski J., Poezje, Warszawa 1983.

Zahorska S., Smocza 13, Rzym 1945.

Żukowski T., Kręgiem ostrym rozdarty na pót. O niektórych wierszach K.K. Baczyńskiego z lat 1942-1943, „Teksty Drugie” 2004, nr 3. 